\title{
CHIRONOMIDS AND THEIR BUCCAL DEFORMITIES FOUND IN MAGDALENA RIVER CATCHMENT (COLOMBIA) AND THE DELICACY OF SPATIAL SCALES IN THE TROPICS.
}

\author{
H.W. Riss ${ }^{1}$, L.B. Nazarova ${ }^{2}$, and R. Ospina T. ${ }^{3}$ \\ 1)University of Muenster, Institute of Animal Evolution and Ecology \\ (riss@uni-muenster.de) \\ 2)Kazan State University, Faculty of Ecology (larisa.nazarova@ksu.ru) \\ 3)National University of Colombia, Department of Biology (rospina@ ciencias.ciencias.unal.edu.co)
}

The present study investigated the chironomid fauna from three stretches of the river Magdalena basin: the mouth lagoons at Santa Marta, the floodplain lakes of the middle sector at Mompox and the river Bogotá up to its headwater.

The biological communities of the Ciénaga de Santa Marta have been studied already for some decades, owing to the severe anthropogenic impacts on this extensive aestuary lagoon system at the Caribbean coast of Colombia. To aid recuperation water is diverted from the Magdalena river through artificial channels which causes a high sediment import and, consequently, an accumulation of particle-bound toxic substances, predominantly heavy metals (PERDOMO 1998). However, concentration of heavy metals in sediments was only slightly increased in comparison to other tropical sites (NAZAROVA et al. in press), but still five to ten times lower than in the middle stretch of the river Rhine (STEGGER et al. 2002).

Macroinvertebrate samples were taken from sediments and plant surfaces. The chironomid communities (21 species/morpho-species) were dominated by Goeldichironomus carus,
G. devineyae, 3 species of Chironomus, 1 species of Larsia, and a non-identified tanypodid species. The occurrence of Fissimentum desiccatum is worth mentioning. The frequency of buccal deformities found in larvae was 21 percent in average, which represents a conspicuously high proportion (NAZAROVA et al. in press).

With respect to these findings more samples were investigated from oxbow lagoons of the river Magdalena and from the river Bogotá, which accounts for a major part of the contamination by domestic and industrial waste water introduced into the basin. Over both reaches heavy metal concentrations in the sediments varied over a wide range, reflecting moderate to high contamination (NAZAROVA et al. in press), i.e. comparable to river Rhine sediments (STEGGER et al. 2002).

In the warm lowland stretches chironomid communities (16 sp./msp.) were dominated by several species of Chironomus, Goeldichironomus and Beardius. In contrast to the significantly high level of organic and heavy metal contamination deformity frequencies ranged from 1.3 to 9 percent only. 
In the temperate highlands, species of Polypedilum, Parachironomus, as well as orthocladiids (Limnophyes, Orthocladius etc.) dominated the community (24 sp./msp.). Likewise to the above, deformity frequencies varied between 2.0 and 8 percent.

The results nearly force the conclusion that the frequency of buccal deformities in chironomid larvae cannot be explained by a simple correlation with heavy metal concentrations in the studied area. As a first approach, two reasons for this can be assumed: Firstly, heavy metals represent only one of the possible stressors which may induce deformities (NAZAROVA et al. 2001, VERMEULEN 1995, WARWICK 1988). Actually there are no data about other agents in the region, and far less do we know about the role of synergisms on a small spatial scale (e.g. the coincidence with oxygen depletion, sediment particle structure etc.). After all, organic contamination and thus high heterotrophic activity, is a crucial factor that determines the structure of the benthic community in streams and rivers of the investigated region (RISS et al. in press). Secondly, the study itself covers a large spatial scale which stretches over distinct climatic and biogeographic zones. And above all, environmental conditions between the extreme sites are hardly comparable due to the temperature gradient of $18^{\circ} \mathrm{C}$ on the annual average.

In spite of these restrictions, bioindicative assessments like the present one, continue to be of great interest for national environmental agencies and so may provide a certain financial basis for more specific work. Regarding this topic, the focus of interest should aim more on synergistic processes in the microhabitat, and be restricted to one biogeographic region, as was mentioned above. Even if political conditions in the country complicate the realization of such projects, a descriptive approach provides a small, but valuable insight into ecological and physiological processes and by this a useful didactic tool for scientific education.

This work was presented on the 'International South American Congress of Limnology Neolimnos 2002' in Leticia/Colombia with financial support of the DFG.

\section{Bibliography}

NAZAROVA, L.B., H.W. Riss \& A. KAHLHEBER: Some observations of buccal deformities in chironomid larvae Diptera: Chironomidae) from the Ciénaga Grande de Santa Marta, Colombia. Caldasia (in press).

NAZAROVA L.B., L.K. GOVORKOVA, R.M. SABIROV \& Z.V. LATYPOVA 2001. Morphological deformations of chironomid larvae in assessment of Kuybishev water reservoir ecological state. Environ. Radioecol. App. Ecol. 7 (2) 22-27.

PERDOMO, L., I. ENSMINGER, L.F. ESPINOSA, C. ELSTER, M. WALLNER-KERSANACH \& M.L. SCHNETTER 1998. The mangrove ecosystem of the Ciénaga Grande de Santa Marta Colombia. Observations on regeneration and trace metals in sediment. - Mar. Poll. Bull. 37 (8-12) 393-403.

Riss, H.W., R. OSPINA \& J.D. GUTIÉRREZ. Establecimiento de valores de bioindicación para macroinvertebrados acuáticos de la sabana de Bogota. - Caldasia (in press).

StegGer, P., H.W. Riss, E. BLÜBAUM-GRONAU \& E.I. MEYER 2002. Mentum- und Mandibeldeformationen bei Chironomus-Larven (Diptera: Chironomidae) als Testkriterium für Sedimentkontaktteste: Ein kritischer Beitrag. Deutsche Gesellschaft für Limnologie (DGL) Tagungsbericht 2001 (Kiel), Tutzing 2002: 819824.

VERMEULEN A.C. 1995. Elaboration chironomid deformities as bioindicators of toxic sediment stress: the potential application of mixture toxicity concepts. - Ann. Zool. Fenn. 32: 265285.

WARWICK W.F. 1988. Morphological deformities in Chironomidae (Diptera) larvae as biological indicators of toxic stress. Toxic contaminants and ecosystem health; A Great Lakes focus. John Wiley \& Sons: 281-320. 